\title{
A Ciceronian Defense of Democratic Participation ${ }^{1-2}$
}

Xinzhi Zhao

\section{Abstract}

Opposing the usual elitist presentation of Cicero, I identify three arguments favoring democratic participation in De re publica and De legibus. The first sees democratic participation as a demand of the common people, which results from their untamable desire for freedom and must be fulfilled to avoid civil unrest. The second sees it as an instrument to lessen the likelihood of elites' corruption. The third incorporates the previous two under an account of state legitimacy, arguing that democratic participation is just because without it, the civic community under a state's rule cannot be a partnership and hence the state cannot be a legitimate one as a common property of the people. I argue that this account of state legitimacy differs from the one in Pettit's republicanism and may help clarify the normative commitment to the public nature of the state that underlies the current "realist" and "instrumental" defenses of democracy.

Keywords: Cicero, Pettit, Republican freedom, Democratic participation, State legitimacy

\section{Introduction: Cicero and the Role of Democratic Participation in Republican Government}

Republicanism is one of the most important developments in contemporary political theory. Advocates of republicanism have argued that it can inform and enrich democratic political theory and practice.

\footnotetext{
I I want to thank Daniel Kapust for his helpful comments on the earlier versions of this paper. I would also like to express my appreciation for the anonymous reviewer's careful reading of my manuscript, constructive feedback, and useful suggestions for additional literature, which helped improve the manuscript.

2 The following abbreviations are used to denote the dialogues by Cicero cited in this paper: Rep. $=$ De re publica (English translation: On the Republic, or On the State), Leg. = De legibus (English Translation: On the Laws), De or. $=$ De Oratore (English translation: On the Ideal Orator).
}

\section{$(\infty)$ EY}

Direito autoral e licença de uso: Este artigo está licenciado sob uma Licença Creative Commons. Com essa licença você pode compartilhar, adaptar, para qualquer fim, desde que atribua a autoria da obra, forneça um link para a licença, e indicar se foram feitas alterações. 
In Republicanism (1997), the major work that reformulates the historical republican tradition and lays the theoretical foundation for contemporary republicanism, Philip Pettit (1997, p. 183-200) argues that democratic participation in the form of effective "contestation" against the results and procedures of governmental decision-making is the necessary instrument to fulfill the republican freedom as non-domination. In On the People's Terms (2012), Pettit refines his theory of "contestatory democracy" by incorporating it into a republican theory of political legitimacy. He identifies the legitimacy of a state as the presence of an "individualized", "unconditioned", and "efficacious" system of "popular control" (PETTIT, 2012, p. 167) over the state's imposition of a social order and thus a "robust absence" of domination in the relationship between citizens and their state (PETTIT, 2012, p. 24).

While his works represent the most philosophically rigorous articulation of contemporary republicanism, Pettit sees (2012, p. 19) his theory as building on a republican tradition that he traces back to the ideas and practices of the Roman Republic. More specifically, Pettit (2012, p. 5-6) frames his theory as the modern update of the "three core ideas" - "freedom as non-domination, the mixed constitution and the contestatory citizenry" - that he identifies in the beginning of the historical republican tradition in the Roman Republic. Yet can we really find a firm defense of democratic participation in the political thought of the Roman Republic? If we can, does this ancient defense of democratic participation bear any concrete resemblance to what claims to be its modern echoes in contemporary republicanism? If there is a difference between the ancient defense and the modern one, does this difference have any relevance to the theory and practice of democracy in the $21^{\text {st }}$ century?

As the foremost Roman political philosopher of the Republic, Marcus Tullius Cicero stands at the beginning of Pettit's genealogy of the republican tradition (PETTIT, 1997, p. 5, 284, 2012, p. 6). Yet in studies of Roman political thought, Cicero is far from being seen as an unequivocal advocate for encompassing the voice of plebeians or the common people in the governance of a true republic. Given his own wealthy background and his opposition to the poor's demands for land distribution in the turmoil of the late Republic, Cicero has often been depicted as "a Roman 
conservative" who holds an elitist view and is skeptical of popular judgments (FREDE, 1989, p. 89) - see also Urbinati (2012) and Wood (1988). While it is shown that Cicero's exemplary constitution has changed from "a liberal form of aristocracy" in his earlier speech Pro Sestio to the tripartite mixed constitution that contains democratic elements in De re publica (ASMIS, 2005, p. 389-390), Cicero's acknowledgment of democratic participation in De re publica has nonetheless been described as being "little more than nominal" (FREDE, 1989, p. 87). This is because this earlier reading by Frede (1989, p. 86) ascribes Cicero's incorporation of the "freedom" of the common people into the mixed constitution to his being influenced by Aristotle's idea of "participation in the government". Therefore, Cicero's acknowledgment of democratic participation is interpreted as a mere result of his reliance on an "Aristotelian source" of an "anonymous peripatetic" rather than a reflection of his original ideas (FREDE, 1989, p. 87-89).

Different from the earlier scholarship, recent research emphasizes Cicero's divergences from his Greek sources on conceptions of the state and the mixed constitution and ascribes more originality to Cicero's key political ideas. While the first among them (WOOD, 1988) situates Cicero's social and political thought in the class relations of the Roman society, others (SCHOFIELD, 1995; ASMIS, 2004; ATKINS, 2013) focuses more on the theoretical aspects of Cicero's definition of the state (res publica) as "a 'thing' of a people (res populi)" and his definition of the community of a people as a "partnership (societas)". They argue that these definitions are based on a Roman experience absent in the Greek thought and practices and that they constitute Cicero's unique contribution to Western political philosophy. They also argue that Cicero's vision of "the best practicable regime" in De re publica, due to its moral orientation and its advantage of being able to manifest itself through generations of practices in history, represents a new model of the mixed constitution that differs from the ones in Polybius's Histories and Plato's Laws (ASMIS, 2005; ATKINS, 2013).

On the issue of democratic participation, while Frede (1989) sees Cicero as being more elitist and less "democratic" than Aristotle, recent 
scholarship on Aristotle no longer associates the latter's idea of active citizenship with a favor for democratic participation. It has been shown in his vision of politeia, which is ruled by "the many" (to pletthos) and is "the best regime of which most cities are capable" (BALOT, 2015, p. 110), Aristotle actually identifies "the many" not to "all native adult males" but to a smaller "middling" class (hoi mesoi) (SAMARAS, 2015, p. 123). This means that Aristotle associates active citizenship only with a smaller, homogeneous group rather than with all free-born males. When Aristotle does advocate for a mixture of oligarchical and democratic principles and thus the participation of both the rich and the poor in the government of mixed regimes, it has been shown that his position has "little to do" with his normative concern about justice but is mainly motivated by a practical consideration against "civil unrest" (SCHÜTRUMPF, 2015, p. 171). In short, while Cicero's limited affinity for democratic participation was ascribed to his vague intellectual connection to Aristotle, now Aristotle himself is shown to be far from demonstrating "[...] a pro-democratic stance, as long as democracy is understood as the constitution in which all native adult males [...] have full citizenship and the Assembly is sovereign" (SAMARAS, 2015, p. 123).

If we should no longer only rely on Aristotle to makes sense of Cicero's favor for democratic participation, then on what basis can we understand Cicero's view on the matter? Building on the recent literature and a close reading of Cicero's De re publica and De legibus, this paper argues that we can isolate three different sorts of arguments in favor of democratic participation from the two dialogues. ${ }^{3}$ The first of the three arguments is

3 I chose to focus on Rep. and Leg. because, although the two dialogues are preserved only in fragmentary conditions, they still contain the best available theoretical articulations of Cicero's key political ideas concerning the nature of the state and its constitution. More expressly, my point is that, while in many other writings Cicero discussed directly or indirectly the role of plebeians in the politics of Rome and implied his views towards plebeians' political influence at his time, it is only in Rep. and Leg. that we can find Cicero's theoretical arguments concerning the importance of democratic participation. These arguments are theoretical because they are parts of Cicero's attempt to offer a systematic examination of the nature of the state and the civic community, typology of regimes, and advantages and disadvantages of different regimes in the two dialogues. As I am interested in identifying what theoretical arguments that Cicero has offered in support of democratic participation, rather than recovering every aspect of Cicero's attitude towards plebeians' political role or determining whether Cicero himself could be seen as a democrat or not, focusing on Rep. and Leg. should suffice for my purpose. Therefore, in part to distinguish my project from a comprehensive historical 
grounded on the necessity of avoiding civil unrest and preserving political stability, the second on the lessened likelihood of corruption given popular activity, whereas the third contains a stronger normative stance, arguing that democratic participation, as what the common people demands on the basis of their being a part of the civic community that contributes to the collective enterprise, must be respected in conformity to the kind of justice required by the nature of the civic community as a partnership.

I argue that the three arguments can support a republican account of democracy that, on one hand, bears a theoretical resemblance to Pettit's republicanism, whereas, on the other hand, cannot be fully combined with Pettit's theory due to Cicero's unique prioritization of the public nature of the state and relevant claims of justice over concerns of individual freedom. I further argue that this unique, irreplaceable feature of the Ciceronian account helps clarify the normative foundation of the contemporary "realist" or "instrumental" defense of democracy, which endorses popular participation not for its intrinsic values or any epistemic merits, but for its superiority in preventing "state capture" by "elite entrenchment" (ACHEN; BARTELS, 2016; BAGG, 2018).

In what follows, I will first briefly explain what I mean by "democratic participation” when analyzing Cicero's ideas and explain why this notion, despite its historical embeddedness in the Roman political practices, might still be relevant to our contemporary discourse on democracy. After clarifying the meaning of democratic participation in the two dialogues, I will then delineate the three arguments in support of it that can be identified in the speeches of the major speakers in Rep. and Leg. I will show that unlike Aristotle, who reserves active citizenship to a small, socially homogeneous group with an aim to promote its common way of

recounting of Cicero's attitude concerning plebeians' political role, I entitled this paper "A Ciceronian Defense of Democratic Participation" instead of "Cicero's View on Democratic Participation". Another reason why I called the justifications of democratic participation I discerned in the two dialogues "Ciceronian" rather than "Cicero's" is that, they are not offered by Cicero in the first person, but come from the speeches of the major speaker in each dialogue: "Scipio" in Rep. and "Marcus Cicero" in Leg. While we may identify them as Cicero's spokesmen, I chose to call their arguments "Ciceronian" rather than "Cicero's". This is because the fragmentary condition of the two dialogues makes it difficult to reconstruct an authoritative and coherent account, which we can unequivocally claim to be Cicero's own view, among the multiple voices conveyed in the dialogues. 
life, Cicero expands political participation to all social orders of the civic community and sets the aim of the community as the fulfillment of the advantages common to all its parts rather than the perfection of a way of life peculiar to one social group. In the fourth section, I will explore the theoretical similarities and differences between the Ciceronian defense of democratic participation and the "individualized, unconditioned, and efficacious system of popular control" (PETTIT, 2012, p. 167) over the state, which generates the republican form of political legitimacy in Pettit's theory. Finally, I will identify the contemporary relevance of revisiting Cicero in an age when democracy is under attack from various versions of "epistocracy" (BRENNAN, 2016) or "meritocracy" (BELL, 2015). I suggest that the unique feature of the Ciceronian account, which defends democratic participation not in the name of freedom per $s e$ but for the sake of affirming justice and the public nature of the state, may help justify the superiority of democracy against its contemporary critics who advocate for the rule of elites.

\section{The Meaning of Democratic Participation in De re publica and De legibus}

When analyzing Cicero's texts, I use "democratic participation" to denote the participation of the common people, or plebeians, in the government of Cicero's mixed regime. For Cicero, the government of a state is characterized by "the kind of deliberation" or "deliberative body" (consilium) that rules the state, and to participate in the government means to take some part in the ruling deliberation (Rep. I. 41). Given that Cicero defines a state (res publica) as "a 'thing' of a people (res populi)" and a people as "[...] a gathering of a multitude formed into a partnership (societas) by an agreement about right (ius) and a sharing of advantage" (Rep. I. 39), we can infer that what the government should deliberate are the rules of distributing rights and advantages in public affairs and that these rules should be acknowledged and abided by all citizens. For Cicero, this deliberation can be conducted either by one man, by certain select men, or by the common people, and he defines the three simple types of regime or constitution - kingdom or monarchy, aristocracy, and democracy or the popular government - according to who undertakes 
the deliberation (Rep. I. 41). According to Cicero, "the best practicable regime" (ATKINS, 2013, 97) is "a moderation and mixing together" of the three simple types of regime (Rep. I. 45), which allows all social classes to exert some influence over the ruling deliberation, though the degrees and forms of their participation should be different for different classes. More specifically, the government in the mixed constitution, exemplified by the Roman Republic, should encompass "[...] enough power (potestas) in the magistrates, enough authority in the deliberation (auctoritas) of the leading men, and enough freedom (libertas) in the people" (Rep. II. 57).

For Cicero, the participation of the common people in the ruling deliberation, as the fulfillment of their demand for freedom, has concrete embodiments in the political institutions and practices of the Roman Republic. In his recounting of the history that culminates in the formation of the exemplary mixed constitution of the Roman Republic, "Scipio", the major speaker in Rep., takes into account the establishment of the system of centuries and centuriate assembly (Rep. II. 39-40) as well as the institution of the office of the tribune of plebs (Rep. II. 57-59). The centuriate assembly, composed of all roman citizens divided into 193 centuries according to their amount of wealth, not only carries legislations as the tribal assembly and the assembly of the plebs, but also elects chief magistracies including praetors and consuls (TATUM, 2009, p. 249). On the other hand, while plebeians can vote in legislations and elections as members of a tribe or a century at various assemblies, the office of the tribune of the plebs, which is assumed and elected only by plebeians, functions with a particular aim to defend the interests of the common people as a class and "curtail the power and influence of the senate" (Rep. II. 59). Moreover, in Leg., when delineating the laws that can best strengthen the Republic, the major speaker "Marcus Cicero", while seeking to increase the senate's power by giving it the final authority in policy-making (Leg. III. 28), still endorses the functioning of the office of tribune (Leg. III. 19-26) and people's voting by ballots in "electing a magistrate and in judging a defendant and in a proposal of laws" (Leg. III. 33). In fact, he defends these institutions of democratic participation against his interlocutors' proposal to reduce the plebeians' political influence by abolishing the office of tribune and changing the form of popular voting from voting by ballots to voting by 
voice. In addition to supporting the office of tribune and voting assemblies, Cicero also acknowledges the political influence of the plebeians via other channels. For example, he emphasizes the importance of winning the support of plebeians via orations at contiones (De or. II. 334,337-340). According to W. Jeffrey Tatum (2009)'s examination of the "democratic dimension" of Roman politics, unlike at voting assemblies, participants in a contio do not vote or make any formal decisions on elections or legislations; instead, contiones are occasions where magistrates mobilize citizens to attend a political candidate's canvass (p. 251) and where “[...] hopeful legislators explicated and justified their propositions, while their opponents endeavored to persuade the public to reject them" (p. 253). However, the popular opinions formed through persuasion at contiones are likely to influence the later voting results (TATUM, 2009, p. 253-254).

We may hence roughly summarize Cicero's notion of democratic participation as enfranchising the common people and allowing their opinions to influence the ruling deliberation through electing tribunes to protect their class interests against patricians and through voting in all legislations and competitive elections of magistracies. According to Cicero, the plebeians' rights to participate in the ruling deliberation are achieved through their pursuit of "freedom". Similar to our contemporary understanding of republican freedom as non-domination, Cicero understands freedom as a status of not being controlled by an arbitrary will of another agent, like how a slave is dependent on the will of a master (ARENA, 2012, p. 79; ATKINS, 2018, p. 42-43). Yet in the Roman society, where members of different social orders do not enjoy equal political rights, Cicero sees freedom less as a universal good for all citizens of any state, but "as the particularly democratic element in the [mixed] constitution" (ATKINS, 2013, p. 109). The discussion of freedom in his dialogues thus represents an early effort to justify the most basic level of political participation by the common people before the equality of political rights for all citizens became a widely acknowledged ideal later in the Western history.

As Nadia Urbinati (2012) rightly points out, Cicero's notions of freedom and the democratic participation, fall short from anticipating 
the egalitarian aspect of our contemporary ideal of democracy. Indeed, Cicero's mixed constitution does not seek to combat the social inequalities between patricians and plebeians through an equal distribution of political rights among all individual citizens. In fact, various specific institutional arrangements in his mixed constitution, including the restriction of the candidacies of magistracies exclusively to patricians, the limitation of the membership of the senate exclusively to those who have been magistrates, and the division of centuries - the basic voting units of the centuriate assembly - according to wealth, all intend to render the nobles and the wealthy a much greater influence in the ruling deliberation. However, Cicero nonetheless seeks to channel the demands of the common people into the ruling deliberation by letting them elect tribunes to protect their interests and enfranchising them in legislations and competitive elections of all magistracies. Therefore, his notion of political participation, though not egalitarian, still corresponds to the most fundamental component in our contemporary definition of what counts as "democratic," i.e., the "electoral component", defined as "[...] making rulers responsive to citizens through competition for the approval of a broad electorate during periodic elections" (LINDBERG et al., 2014, p. 160). In this sense, while revisiting Cicero's defense of democratic participation may contribute little to the promotion of equal political rights among all individual citizens, it may still help us respond to the contemporary attacks on the basic "electoral component" of democracy. Such attacks include Jason Brennan (2016)'s "epistocracy", which aims to disfranchise citizens who have little political knowledge, and Daniel Bell (2015)'s "meritocracy", which seeks to remove competitive elections above the local level (BAGG, 2018).

\section{Three Arguments in Favor of Democratic Participation in De re publica and De legibus}

Why must democratic participation, or participation of the common people, be incorporated in the mixed constitution? From the speeches of "Scipio" and "Marcus Cicero", we can identify three different accounts that explain the importance of allowing some basic sorts of democratic 
participation in the government. We may develop a Ciceronian defense of democratic participation based on the three accounts.

\section{I Avoiding Civil Unrest and Maintaining Stability}

In the first account, democratic participation, as the means to fulfill freedom as non-domination, is depicted as an ineradicable desire of the common people, which, if completely left unsatisfied, will drive the people to rebel against the rule of the king or the aristocrats, and thus threaten the stability of the republic:

But behold, the people (populus) shouts in its strongest voice that it is willing to obey neither one man nor a few, that not even to wild animals is anything sweeter than freedom, that all men lack this whether they serve a king or aristocrats. (Rep. I. 55).

[On Pompeius's resumption of the tribunician power:] He had to see not only what was best but also what was necessary. He sensed that that power could not be withheld from this city. Indeed how could our people, who had desired it with such effort when it was unknown, have been able to do without it when it was known? It would not have been the part of a wise citizen to leave for a populist citizen, in a ruinous manner, a cause that was not ruinous and that was so popular that it could not be withhold. (Leg. III. 26).

How strong this desire for freedom is depends on the specific contexts. When the common people are unjustly ruled by one man or a group of men - like Tarquinius Superbus or the second decemvirate who are "beset by iniquity and passions" (ASMIS, 2004, 584; Rep. I. 42) and whose rule is thus characterized by cruelty and licentiousness (Rep. I. 44), the desire will lead to a ferocious rebellion against the unjust rule. It may also become stronger in situations where the right to influence the ruling deliberation once granted is taken away from a people who have already tasted the sweetness of freedom, as in the case of the tribunician power quoted above. In such cases, the resentment against the loss of freedom will drive the common people to rebel "in a ruinous manner". Yet in other contexts, the desire for freedom and democratic participation may be milder, directed not towards rebellion but conditional obedience - "they wanted not to obey no one, but not always to obey one man" (Leg. III. 4) - or takes the form of fear or anxiety: "[...] the fear will always threaten that an unjust king may emerge (as very often happens). 
Therefore, the fortune of the people is fragile when it depends on the will or habits of one man" (Rep. II. 50).

However, despite being flexible in intensity, in all cases, this desire manifests itself as a need to have at least some say in the government, i.e. not to let any other agents deliberate and determine one's rights and advantages for oneself completely, but to participate in the deliberation and make the decision by oneself to some extent. The two speakers do not offer any normative justification for a need for democratic participation in this argument, but they still treat it as a hard fact that cannot be ignored by any wise statesmen and legislators: "Reason was perhaps lacking in this, but the nature of republic itself often overcome reason" (Rep. II. 57). This is because if the hard fact is not tackled, then there will be instability due to the contention between social classes, or even rebellion and destruction. However, the class contention can be eased and thus stability attained if the common people's need to participate in the government is to some extent satisfied, even just nominally in some circumstances, i.e., the common people need not necessarily be given a substantive influence over the ruling deliberation and actually control their own lives, but should be given only the impression that they are able to do so, as in the cases of the Servian reform (Rep. II. 38-39) and the order of Publicola (Rep. II. 55). Alternatively, there will be even more respect and support from the common people to the authority of the aristocrats:

But see our ancestors' wisdom in that matter: When the Fathers conceded this power [tribunician power] to the plebeians, the weapons fell, the sedition was extinguished, a compromise was found so that the less important men thought that they were equalized to the leading men. In that one thing was the salvation of the city. (Leg. III. 24).

[On voting by ballot:] I bestow this freedom on the people so that respectable men may be strong and use their authority. ... the ballot condemns fewer men than voice usually does, because it is enough for the people to be permitted [to vote]. If that is retained, the rest of the will is transmitted through influence or gratitude. ... Therefore, my law gives the appearance of freedom; the authority of respectable men is retained; a cause of contention is eliminated. (Leg. III. 39).

In short, according to the first account, democratic participation needs to be incorporated into the mixed constitution, not because the common 
people's desire for freedom is just or rational, but because the political consequence this incorporation will bring about - stability - is desirable.

\subsection{Reducing the Likelihood of Elites' Corruption and Correcting Unjust Rule}

In addition to the first account, there is another defense of democratic participation offered by Scipio in Rep., which is also based on consequentialist grounds. Here, the desirable outcome is not only stability, but the correction of the unjust rule of a corrupt king or aristocrats. While stability might be maintained on the condition of only a nominal acknowledgment of the freedom of the common people, to correct unjust rule of the elites would require the common people to have a substantive influence in government.

The second consequentialist argument is evident in Scipio's appreciation of the exile of Tarquinius Superbus and the abolition of kingship as well as the people's rise against the addition of "the two tables of unfair laws" by the second decemvirate (Rep. II. 45-49; II. 62-63). As mentioned earlier, in both cases, the elites are driven by their own self-interests and passions in their rule and thus rule unjustly. According to Scipio, it is the people's actions to liberate themselves from being dominated by bad rulers that save the republic from unjust rule.

For Scipio, that the ruler(s) may become unjust is not only seen in individual cases, but is a structural defect inherent in any simple type of regime.

[...] it seems good for there to be something preeminent and regal in the republic, for something else to be shared with and assigned to the authority of leading men, for certain things to be saved for the judgment and will of the multitude. This constitution has, first, a certain equality (aequabilitatem), which free men can scarcely be without for very long; second, a firmness (firmitudinem), because those primary types are easily changed into their corresponding defects - so that a master emerges from a king, a faction from aristocrats, a mob and confusion from the people - and because those types themselves are often changed into new types. That does not usually happen in this combined, moderately mixed constitution of the republic unless there are great vices in the leading men. (Rep. I. 69).

In the cases of monarchy and aristocracy, the former will be easily turned into a tyranny when one king begins to act unjustly or the kingship 
is transformed from a just ruler to an unjust one (Rep. I. 64), whereas the latter will lose its substance as the rule of the best men when their rule is no longer based on their superiority in judgment and virtue but on their birth and wealth (Rep. I. 51). In republics governed by a single social order, the corruption of the ruling elites happens very easily, because of the lack of external checks; whereas if democratic participation is introduced into a regime, the common people's desire to break free from unjust rule will make such corruption less likely to happen, or, once the corruption takes place, the people's desire and action to regain their freedom and right to participate in the government can correct the unjust rule. Here, the "firmness" of the mixed constitution is understood not only as maintaining the stability of the current form of the regime - which is a value-neutral enterprise - but also in terms of the lesser likelihood for the current regime to degenerate into a more unjust one. Its "firmness" in containing the regime's moral degeneration is thus one of the two reasons why Scipio ranks all simple types of regimes below the mixed constitution and makes the mixed constitution not only involve kingly and aristocratic elements but also democratic participation.

\subsection{Fulfilling Justice as Required by the Nature of the Civic Community as a Partnership}

As shown in the passage quoted above, another reason why Scipio prefers the mixed constitution to simple ones is that it acknowledges "[...] a certain equality, which free men can scarcely be without for very long" and he prioritizes this merit of the mixed constitution to its "firmness" (Rep. I. 69). This prioritization brings us to his third argument of democratic participation.

The third argument differs from the previous two in that it does not value democratic participation for the desirable political consequences it may bring about, but because it is an indispensable part of a certain kind of justice implicated in the nature of the state as "the 'thing' of a people":

[...] who would call "a 'thing' of a people" (that is, a republic) at the moment when all together were oppressed by the cruelty of one man, and there was neither the single bond of right nor the agreement and partnership (societas) of an assemblage, which is a people? ... Nothing belonged to the people, and the people itself belonged to one man. Therefore, 
where there is a tyrant, there is not a defective republic (as I said yesterday); but, as reason now compels, it must be said that there is no republic (res publica) at all.

[...] What about when the decemvirs at Rome were in their third year, immune to appeal, when freedom itself had lost its legal bulwarks? There was no "'thing' of a people." On the contrary, the people acted in order to recover its "thing". (Rep. III. 35).

Res publica ruled by an unjust ruler, who does not acknowledge freedom of the people, is not res publica at all. This is still the case, even when the ruler is just, as long as his ruling deliberation does not encompass freedom of the people:

So even if the famous Cyrus the Persian was the most just and wisest king, that does not seem to me to have been a greatly desirable "thing' of a people" (for that is what a republic is, as I said before), since it was ruled by the nod and [the will] of one man. In the [same] way, if our clients the Massilians are ruled with utmost justice by select, leading citizens, there is nevertheless in this condition of the people a certain similarity to slavery. (Rep. I. 43). In a republic where there is one man with perpetual power, especially royal - even if there are in it both a senate, as there was at Rome when there were kings and at Sparta under the laws of Lycurgus, and even some right of the people, as there was with our kings - nevertheless, the royal name is eminent, and a republic of this sort cannot be called, or be, anything but a kingdom. ... this form is that in which the citizens' safety, equality, and leisure are ruled by the perpetual power, justice, and entire wisdom of one man. Altogether many things are lacking for a people who is under a king - in the first place freedom, which does not consist in employing a just master [...]. (Rep. II. 42-43).

The two passages constitute a rejection of the rule of what we now call "benevolent dictator(s)": Even if the $\operatorname{ruler}(s)$ of a state is fully just - i.e., they are not driven by their private or factional interests but rule according to their judgments of the common advantages - their rule nonetheless reduces other citizens below the free status required by their citizenship and down to a dependent situation similar to slaves. The people lacks "freedom", as long as the rulers do not allow them to exert influence over the ruling deliberation themselves. So there is a distinction between the character of the rulers and the character of their rule: a deficient rule may come from a perfectly just ruler, as long as they do not acknowledge the freedom of ordinary citizens and incorporate this element into ruling deliberation. It is further noteworthy that Scipio identifies the deficiency of the rule also as the deficiency of the state under the rule: the deprivation 
of freedom of the common people not only indicates a defective form of ruling, but also suggest that the state under such a rule falls short of being a true republic.

Therefore, Res publica under an unjust rule is not res publica at all. While "res publica" was translated as "the republic" in the Fott's translation (2014) quoted above, Asmis (2015, p. 377) reminds us that this word is "more accurately" translated as "the state", as the subject of interest in Rep. is not just the Roman Republic but states in general. By contrasting a state with "no res publica at all", Scipio implies that his very definition of the state contains a normative dimension, that for a political entity to deserve to be named a "state", it must be ruled justly, and freedom of the people is an intrinsic component of the just rule.

Yet why should the just rule encompass freedom of the people? And, why is a constitution that enables the common people to exert their influence over the ruling deliberation the one that best matches the nature of the state? To shed light on the inherent connection between freedom, the just rule, and the nature of the state here, we need to revisit Scipio's definition of the state, as Scipio reminds his interlocutors to do:

A republic is a "thing" of a people (res publica res populi). A people (populus), further, is not just any gathering of humans that has come together in any way at all; but it is a gathering of a multitude formed into a partnership (societas) by an agreement about right/justice (iuris consensu) and a sharing of advantage (utilitatis communione). (Rep. I. 39).

The novelty of this definition, as many scholars have pointed out, lies in the detachment of the state from the people: the state is not identified as the civic community itself, as it was in the ancient Greek thought, but a thing (res) of the civic community (ASMIS, 2004; ATKINS, 2013, 2018; SCHOFIELD, 1995; WOOD, 1988). Among these studies, Schofield (1995, p. 66) is the first one that interprets this detachment as a forecast of the modern notion of "legitimacy". He argues that this detachment implies that the state is associated with an "impersonal authority" distinct from and less natural than the original power of the civic community. Therefore, one should not take the existence of the state authority for granted and only ask who is just enough to claim for the authority, as the Greeks did; one should also ask whether the very existence of the state authority over 
the civic community is legitimate or not (SCHOFIELD, 1995, p. 67). Therefore, through the language of "legitimacy", Cicero's argument that "a state under an unjust rule is not a state at all" is translated as "a state that rules the civic community unjustly is not a legitimate state".

Yet what makes the rule of a state authority over its civic community a just one? And, on what grounds must this just rule, which generates the legitimacy of the state authority, encompass democratic participation? Schofield (1995) answers these questions by invoking the idea of the "sovereignty" of the people (p. 77, 80, 82), which he argues is implied in Scipio's definition of state as a "thing" of the people. In Schofield's reading, a state's rule over a civic community can only be legitimate if it is derived from the popular sovereignty of the latter: the people has original "rights" over "its own res", i.e. the state, and the authority to rule the state is a result of people's "entrusting" of their state to a government (p. 77). Therefore, state authority is only legitimate when the trustee rules the state in such a way that the state under the rule remains a thing of the people rather than a private property of the trustee. Schofield further identifies the condition for the state to remain a thing of the people to be the preservation of people's "freedom": while the people entrusts the state to a government, they must be able to have the ultimate control over the state, and for the government - as the trustee - to have a legitimate authority, it must acknowledge the people's "rights" to the ultimate control over the state (1995, p. 74, 77).

I agree with Schofield's basic argument that Cicero's detachment of a state from a people brings to light the question of the legitimacy of state authority, which was unknown to Greek thinkers. However, I find his overall interpretation too "modern" to be seen as a faithful summary of Cicero's thought on the question of legitimacy. While the Roman term "ius" is regarded as one of the origins of the modern concept "right" (TUCK, 1993), the kind of "right" that justifies the sovereignty of a people, understood as the collection of all individual citizens of a state, is a distinct modern invention. Indeed, it is hard to find in Cicero's texts an unequivocal articulation of something similar to the modern idea of "popular sovereignty", which is grounded on each individual citizen's 
inherent freedom to control their own affairs and which in turn predicates the legitimacy of the state on the state's acknowledgment and protection of the inherent right of all citizens. This is because what is implied in the modern idea "popular sovereignty" - a unitary civic body and the equal political rights of every individual citizen - does not match well with Cicero's usages of two key terms, "people (populus)" and "freedom (libertas)". As the passages quoted in previous sections show, and as Asmis (2004, p. 577) has already pointed out, while Cicero sometimes uses the word "people (populus)" to refer to "the whole Roman citizenry", other times he uses it "in a narrower sense", denoting a particular social order among citizens, i.e., "a grouping of people that differs from the senatorial aristocracy". Corresponding to this narrower meaning of "people" as a particular social class, Cicero uses "freedom" to designate the demand of that particular social class - the common people that "differs from the senatorial aristocracy" - for having an influence in the public deliberation (Rep. I. 55; Leg. III. 26, 39). It is true that Cicero, when using "people" to denote "the whole Roman citizenry", generalizes "freedom" to the whole citizenry as a minimal character that distinguishes a citizen from a slave, and thus as a rightful demand that any free-born person could make according to his status as a citizen, but he never says that it is this freedom that constitutes the people. Instead, what he says is that a people is a "partnership (societas)," formed "by an agreement about right/justice (iuris consensu) and a sharing of advantage (utilitatis communione)". There is no mentioning of freedom in this definition.

Therefore, legitimacy of the state authority in Cicero's definition should not be seen as directly derived from the state's acknowledgement and protection of the freedom of each individual citizen. Instead, legitimacy lies in the state authority's acknowledgement and protection of the nature of its civic community as a partnership (societas). In other words, freedom, as a citizen's demand for not being dominated by others as a slave, only matters on the issue of legitimacy as a necessary component of the civic partnership; it does not directly constitute political legitimacy.

What kind of community can be counted as a "partnership" then? Recent scholarship has shown that that the term "partnership" originally 
refers to the collective ownership of a property in the Roman legal practice (ASMIS, 2004, p. 580; ATKINS, 2018, p. 26, 52; HAMMER, 2014, p. 46). A partnership, in this original social context, is understood as "an agreement to contribute property or work or both to the prosecution of a common aim" (ASMIS, 2004, p. 580). This agreement should be governed by a certain kind of justice defined as a fair distribution of contributions and rewards to each party in the partnership (ARENA, 2012, p. 152-65). For the distribution to be fair, each partner need not contribute to the collective enterprise or be rewarded with the same amount or in the same way, but the partners have to "receive a share of the profits in proportion to their contribution" (ASMIS, 2004, p. 581). Accordingly, "[...] all partners have an obligation to deal ex bono et aequo, 'fairly,' with one another", and each partner has "a right to some share in the benefits that resulted from the partnership" (ATKINS, 2013, p. 134). Using the term "partnership" in the political context, then, means that all parts of the civic community, or the community of a people, should treat each other fairly when dealing with the distribution of the contributions and benefits of their common property the state. In other words, it is only when each part of a people adheres to the justice and the common aim of their partnership that their community can be called a partnership. Accordingly, it is only when the state, governs the distribution of contributions and benefits of the civic community in a way that preserves the community's nature as a partnership, that its rule can be seen as just and the state itself can be said to have a legitimate authority.

But what parts of a people should be united as a partnership? And, what are the justice and the common aims - in other words, the "agreement about right/justice (iuris consensu)" and the "sharing of advantage (utilitatis communione)" - that governs the distribution of contributions and benefits of this political partnership? Here I agree with Asmis (2004, 2005), who argues that the answers to these questions should be found in Scipio's account of the history of the Roman Republic as the exemplary state governed through a mixed constitution (Rep. II. 4-63), as well as Scipio's argument that the existence of the Roman Republic as the exemplar of a true state depends on its collective commitment to the "other-regarding" (ASMIS, 2004, p. 587) natural justice rather than a conventional justice 
(Rep. III 21-36). In Scipio's account of the history of Rome that culminates in the Roman Republic, all parts of the Roman citizenry - not only kings and senates but also the common people; not only patricians but also plebeians - contribute to the formation and perfection of the Republic (e.g. Rep. II. 39-40), so the partnership of the Roman people must encompass all social orders among free-born citizens. The Republic is the exemplary state because its ruling deliberation promotes, first, a "harmony" of all parts of the Roman people rather than discords (Rep. II. 69), and second, advantages common to all social orders, i.e., "the health of citizens, the safety of cities, and the quiet and happy life of human beings" (Leg. II. 11; Rep. IV. 1), rather than a way of life peculiar to a certain social class. It is this maintenance of the harmony of different social orders - a manifestation of the other-regarding, natural justice of human communities (Rep. I. 1, 39) - and the fulfillment of the common advantage that keeps the Roman people as a true partnership, and this in turn makes the Roman Republic a legitimate state.

Then what is the role that freedom plays in the generation of the legitimacy of a state? As noted earlier, the harmony or justice of a partnership is achieved through a fair distribution of the contributions and benefits of its members. With respect to the fair distribution that makes a people a political partnership, freedom, and the democratic participation it implies, are essential in two ways: first, as we see in the first argument for democratic participation, freedom is demanded by the common people, who ask for a control over their own lives by having some influence in the government. Under the framework of the civic community as a partnership, this demand for freedom is no longer just an untamable impulse, but a rightful request that should be acknowledged according to the common people's status as citizens who constitute and contribute to the partnership. Second, as we see in the second argument, the common people's pursuit of freedom can help lessen the likelihood of elites' corruption, so freedom is valuable as an instrument to the maintenance and restoration of the natural justice that makes a civic community a partnership. In short, freedom, and the democratic participation it implies, are both an inherent requirement for the civic community to be a partnership and an effective instrument for the civic community to maintain as a partnership. Therefore, while democratic participation does not directly give rise to the legitimacy of a 
state, it is a necessary component of the state legitimacy due to its essential role in making the civic community a partnership.

\section{Cicero versus Pettit on Republican Freedom, Democratic Participation, and State Legitimacy}

As opposed to the elitist, conservative presentation of Cicero in earlier studies, we have seen that a defense for democratic participation can be distilled from Rep. and Leg. This Ciceronian defense consists of three arguments: the first sees democratic participation as a demand of the common people, which results from their untamable desire for freedom as non-domination and which should be fulfilled so as to avoid civil unrest and maintain political stability. The second sees democratic participation as an instrument to lessen the likelihood of corruption of the ruling elites. The third incorporates the previous two arguments under a legal framework of state legitimacy, arguing that democratic participation is rightful or just because without it, the community of a people cannot be a true partnership and thus the state cannot be a legitimate one as a "res" or a common property of the people.

In what sense this the Ciceronian defense of democratic participation still present in contemporary republicanism, which regards Cicero as one of its earliest and major intellectual predecessors? A brief comparison between Cicero's and Pettit's views on freedom as non-domination, democratic participation, and state legitimacy may shed some light on this question.

In all three arguments of the Ciceronian defense, we can find a close connection between freedom and democratic participation, in the sense that if freedom understood as non-domination is to be acknowledged and protected, then there must be some sorts of democratic participation in the ruling deliberation of a state. This close connection is preserved in Pettit's theory, though it is presented with more analytical rigor and is modified according to the modern egalitarian and individualistic context that calls for equal freedom for all individuals. In Republicanism (PETTIT, 1997), Pettit formulates the republican freedom as non-domination as a third conception of liberty, which he sees as a better substitute for both the "negative liberty" in the liberal tradition and the "positive liberty" in the Rousseauian tradition. On one hand, this republican freedom 
inherits its conceptual core from Cicero; i.e., it designates a status free from the domination of another person's arbitrary will that is not under one's control. On the other hand, however, it is also "modernized" by Pettit: unlike Cicero, who sees freedom as non-domination as a rightful demand of a social group, Pettit makes non-domination a universal ideal that requires an equal non-dominated status for every individual. In $\mathrm{On}$ the People's Terms (2012), Pettit further clarifies the necessary social and political requirements for the fulfillment of freedom as non-domination. It requires a just social order that minimizes one's dependence on another's will that is beyond one's control when making choices and, in doing so, realizes non-domination in one's relations with other citizens (PETTIT, 2012 , p. 75-129). Yet given that it is necessary for a state to exist as an agent that imposes this social order (PETTIT, 2012, p. 132-136), the fulfillment of republican freedom also requires the relations between each citizen and the state to be non-dominating (PETTIT, 2012, p. 131). This requirement necessitates a system of "popular control" over the state's imposition of the social order (PETTIT, 2012, p. 146-153) and this system should be "individualized" and "unconditional", in order to reflect the equal nondominated status of each citizen in relation to the state and to realize this equal status in political practices (PETTIT, 2012, p. 168-74). The system should also be "efficacious", in the sense that the system should not only allow citizens to have some sort of influence over the state's decisions and policies but also enable them to impose a direction over the state's decisions and policies, i.e., to effectively orient the state according to their own preferences (PETTIT, 2012, p. 175-179). As Pettit suggests in the last two chapters of $O n$ the People's Terms, the realization of this "individualized, unconditional, and efficacious" system of popular control over the state, as the requirement of freedom in the relations between citizens and their state, is dependent on various forms of extensive democratic participation (PETTIT, 2012, p. 187-292).

The comparison above shows that the observation in the Ciceronian defense-that freedom as non-domination requires democratic participation - is also central to Pettit's theory. Under the same acknowledgment of the connection between republican freedom and democratic participation, Pettit differs from Cicero only by making freedom an ideal that should be equally accessible for all individuals and by offering a more analytically 
rigorous account of popular control. In contrast, on the relationship between freedom and state legitimacy, there is a more fundamental divergence between the two thinkers.

For Pettit (2012, p. 130-136), freedom is the ultimate criterion of state legitimacy; i.e., a state is legitimate if and only if it governs the society in a way that acknowledges and protects the equal non-dominating status of each citizen in their relation to the state. In this sense, although Pettit in general avoids using the language of "right" and "sovereignty" so as to distinguish his republicanism from both liberalism and the Rousseauian tradition, the position and function of freedom as non-domination in Pettit's theory are actually analogous to the position and function of "natural right" in the two traditions from which Pettit wants to keep a distance: both republican freedom and natural right are the cornerstones of their theories, and it is only from them that social justice and political legitimacy are derived. We can find the same structure in the abovementioned Schofield (1995)'s interpretation of Cicero: freedom to control their "res," i.e., the state, is an inherent right of a people, and the legitimacy of a state authority can only be evaluated according to this right. However, as we have shown above, contrary to Schofield's interpretation, it is not from freedom that the ruling deliberation of a state derives its legitimacy; instead, the ultimate source of legitimacy is the natural justice that keeps the community of a people as a partnership. In other words, the ruling deliberation, or, the state authority, can only be legitimate if the civic community under its rule is kept as a partnership. With respect to freedom and the democratic participation it requires, in the Ciceronian account, they are necessary for a state authority to be legitimate not as the ultimate source of legitimacy, but as a rightful demand and a useful instrument that preserve the natural justice that makes the civic community a partnership.

Given these similarities and differences, we may conclude our comparison between Cicero and Pettit in this way: while Cicero and Pettit believe that freedom as non-domination necessitates democratic participation, they have different theories of state legitimacy; Pettit prioritizes freedom and makes both social justice and political legitimacy derivative from freedom, whereas Cicero prioritizes the natural justice that maintains a civil association over freedom when determining the 
legitimacy of a state authority. This is not to say that the change of the prioritization signifies a flaw in Pettit's republicanism; rather, the difference in priority between Cicero and Pettit results from one of the major changes in the modern history of political thought, where individual rights replace natural justice as the bedrock of any modern systems of political theory. However, by making everything dependent on a specific notion of freedom, Pettit makes republicanism irrelevant to those defenses of democratic participation that claim independence to any particular notions of freedom. In contrast, a revisit to Cicero's pre-modern notion of state legitimacy, as the conclusion will show, may help clarify the connection between those defenses of democracy and the republican tradition.

\section{Conclusion: Why Revisiting Cicero in the $2{ }^{\text {st }}$ Century?}

I would like to conclude the paper with an attempt to justify its contemporary relevance: what makes it meaningful to distill a defense of democratic participation from Cicero's dialogues, given that many of his insights have been absorbed in contemporary republicanism and updated there according to the beliefs and practices of modern democracies? Given that Pettit justifies his choice of building his contemporary theory of republicanism on the historical republican tradition by arguing that the latter adds "historical credentials" and "intellectual plausibility" to the former (PETTIT, 2012, p. 19), we may want to know to what contemporary ideas that our revisit to Cicero adds such "historical credentials" and "intellectual plausibility".

Showing that an important historical thinker, who, despite being elitist and skeptical of popular judgments, still favors democratic participation, certainly serves the cause of democracy. In addition to that broad significance, however, I suggest that the third, legal argument in the Ciceronian defense of democratic participation might have a special relevance to our time, when the very basic ideas of modern electoral democracy, including universal suffrage and competitive elections, are under attack by "epistocracy" (BRENNAN, 2016) and "meritocracy" (BELL, 2015) due to the epistemic deficiencies that ordinary voters demonstrate in democratic practices. 
The third, legal argument in the Ciceronian defense presents a unique account of state legitimacy, a pre-modern one in that it derives legitimacy not from any conception of individual liberty, but from a conception of justice that keeps multiple social members with diverse interests and social statuses as citizens of one political community. Democratic participation is valuable in this account not because it is required for realizing freedom per se, but because it is required for fulfilling justice. Indeed, the specific view of justice at Cicero's time may help justify unequal distribution of political rights among different social members; at the most general level, however, if it is extracted from its particular historical contexts, this account of state legitimacy seems to capture a very basic view - by and large independent from any specific notions about individual liberty that many of us still share with Romans with respect to the public nature of the state: the state should be a public entity that brings different social groups together for their common advantages and guarantee fairness in social transactions and interactions, it should preserve its public nature by protecting socially disadvantaged groups and individuals from the harm and exploitation by the elites, and it should also guard itself against the entrenchment of elite interests. Otherwise, the state will not be worth of its name. Democratic participation, in this view, is valuable because it is necessary for the preservation of the public nature of the state.

This argument is in line with the recent rise of what is dubbed as "realist" or "instrumental" defenses of electoral democracy (ACHEN; BARTELS, 2016; BAGG, 2018). Theories in this vein do not seek to justify democracy on the grounds of its intrinsic value, including the intrinsic value of equal political rights, or its capacity for generating any specific desirable decisions or policies; instead, they defend democracy on the basis of its superiority in "resisting state capture" by powerful social groups and preventing "entrenchment" of various elite powers into the state (BAGG, 2018 , p. 892, 894-895), arguing that this superiority is a merit that cannot be duplicated in any forms of "epistocracy" or "meritocracy" (ACHEN; BARTELS, 2016, p. 316-319; BAGG, 2018, p. 895-901). "Realist” or "instrumental" defenders of democracy usually emphasize the pragmatic orientation of their theories, so as to distance themselves from epistemic democrats as well as those who advocate democracy for its connection to 
other normative ideals, such as equal freedom, dignity, and autonomy. Yet nonetheless, their vigilance against any elites' control of the state, and their negative evaluation of such a control as a danger that must be guarded against through democracy, seem to be built on an implicit, normative commitment to the public nature of the state.

This normative commitment is by and large independent to any specific notions of positive or negative freedom, and even to any particular understandings of representation. By recovering the Cicero's notion of state legitimacy in the third Ciceronian argument for democratic participation, this paper shows that this commitment is first articulated in the Roman republican thought, before any particular notions of natural or universal freedom came into being. In the sense, by tracing it back to the republican tradition, the Ciceronian defense of democratic participation brings "historical credentials" and "intellectual plausibility" to the normative commitment to the public nature of the state that underlies the current realist and instrumental defenses of democracy.

\section{References}

ACHEN, C. H.; BARTELS, L. M. Democracy for Realists. Princeton \& Oxford: Princeton University Press, 2016.

ARENA, V. Libertas and Practice of Politics in the Late Roman Republic. Cambridge: Cambridge University Press, 2014.

ASMIS, E. The State as a Partnership: Cicero's Definition of Res Publica in His Work On the State. History of Political Thought, v. xxv, n. 4, p. 569-599, out. 2004.

ASMIS, E. A New Kind of Model: Cicero's Roman Constitution in De Republica. American Journal of Philology, v. 126, n. 3, p. 377-416, out. 2005.

ATKINS, J. W. Cicero on Politics and the Limits of Reason: The Republic and Laws. Cambridge: Cambridge University Press, 2013.

ATKINS, J. W. Roman Political Thought. Cambridge: Cambridge University Press, 2018.

BAGG, S. The Power of the Multitude: Answering Epistemic Challenges to Democracy. American Political Science Review, v. 112, n. 4, p. 891-904, out. 2018.

BALOT, R. The 'Mixed Regime' in Aristotle's Politics. In: SAMARAS, T.; LOCKWOOD, T. (org.). Aristotle's Politics: A Critical Guide. Cambridge: Cambridge University Press, 2015. p. 103-122.

BELL, D. A. The China Model: Political Meritocracy and the Limits of Democracy. Princeton: Princeton University Press, 2015. 
BRENNAN, J. Against Democracy. Princeton \& Oxford: Princeton University Press, 2016.

CICERO, M. T. De Re Publica, De Legibus. Tradução de C. W. Keyes. London: William Heinemann Ltd., 1928.

CICERO, M. T. On the Ideal Orator. Tradução de J. M. May; J. Wisse. New York; Oxford: Oxford University Press, 2001.

CICERO, M. T. On the Republic and On the Laws. Tradução de L. Foot. Ithaca; London: Cornell University Press, 2014.

FREDE, D. Constitution and Citizenship: Peripatetic Influence on Cicero's Political Conceptions in the De Re Publica. In: FORTENBAUGH, W. W.; STEINMETZ, P. (org.). Cicero's Knowledge of The Peripatos. New Brunswick \& London: Transaction Publishers, 1989. p. 77-100.

HAMMER, D. Roman Political Thought: From Cicero to Augustine. Cambridge: Cambridge University Press, 2014.

LINDBERG, S. I.; COPPEDGE, M.; GERRING, J.; TEORELL, J. V-Dem: A New Way to Measure Democracy. Journal of Democracy, v. 25, n. 3, p. 159-169, out. 2014.

PETTIT, P. Republicanism: A Theory of Freedom and Government. Oxford: Oxford University Press, 1997.

PETTIT, P. On the People's Terms: A Republican Theory and Model of Democracy. Cambridge: Cambridge University Press, 2012.

SAMARAS, T. Aristotle and the Question of Citizenship. In: SAMARAS, T.; LOCKWOOD T. (org.). Aristotle's Politics: A Critical Guide. Cambridge: Cambridge University Press, 2015. p. 123-141.

SCHOFIELD, M. Cicero's Definition of Res Publica. In: Powell, J. G. F. (ed.), Cicero the Philosopher. Oxford: Clarendon Press, 1995. p. 63-83.

SCHÜTRUMPF, E. Little to Do with Justice: Aristotle on Distributing Political Power. In: SAMARAS, T.; LOCKWOOD T. (org.). Aristotle's Politics: A Critical Guide. Cambridge: Cambridge University Press, 2015. p. 184-203.

TATUM, W. J. Roman Democracy? In: BALOT, R.K. (org.) A Companion to Greek and Roman Political Thought. New York: John Wiley \& Sons, Inc., 2009. p. 246-259.

TUCK, R. Philosophy and Government 1572-1651. Cambridge: Cambridge University Press, 1993.

URBINATI, N. Competing for Liberty: The Republican Critique of Democracy. American Political Science Review, v. 106, n. 3, p. 607-21, out. 2012.

WOOD, N. Cicero's Social and Political Thought. Berkeley: University of California Press, 1988. 


\section{Uma Defesa Ciceroniana de Participação Democrática}

\section{Resumo}

Ao contrário da habitual apresentação elitista de Cícero, identifico três argumentos a favor da participação democrática no De re publica e De legibus. O primeiro compreende a participação democrática como uma exigência do povo comum, que resulta do seu desejo intransigente de liberdade e deve ser satisfeita para evitar a agitação civil. O segundo a vê como um instrumento para diminuir a probabilidade de corrupção das elites. O terceiro incorpora as duas anteriores sob uma narrativa da legitimidade do Estado, argumentando que a participação democrática é justa porque, sem ela, a comunidade cívica sob o governo de um Estado não pode ser uma parceria e, portanto, o Estado não pode ser legítimo como uma propriedade comum do povo. Eu defendo que esta noção da legitimidade do Estado difere daquela do republicanismo de Pettit e pode ajudar a esclarecer o compromisso normativo com a natureza pública do Estado que está subjacente às atuais defesas "realistas" e "instrumentais" da democracia.

Palavras-chave: Cícero. Pettit. Liberdade republicana. Participação democrática. Legitimidade estatal. 